\title{
Global Marketing Strategic Approaches on Multi National Companies Product Development
}

\author{
Stavros Kalogiannidis ${ }^{1}$, Katerina Melfou ${ }^{2}$, Olympia Papaevangelou ${ }^{3}$ \\ ${ }^{1}$ Department of Regional and Cross Border Development, University of Western Macedonia, Greece \\ ${ }^{2}$ University of Western Macedonia, School of Agricultural Sciences, Department of Agriculture Terma \\ Kontopoulou, 53100 Florina, Greece \\ ${ }^{3}$ Secondary \& Postsecondary Educator, Ministry of Education, Kozani, Greece
}

\begin{abstract}
When it comes to business prospects, all organizations try to implement effective marketing mix strategies to ensure consistent operations. While these strategic approaches help a business sustain product development procedures, it also inflicts a humongous impact on issues concerning product development and promotion. In terms of global marketing, most multinational companies and retail firms aim to implement sustainable marketing mix strategies to build and expand their products or services to grab a considerable portion of foreign market share. This not only helps them to generate the desired revenues but also helps a business to enhance its customer base in the target market. This in turn escalates the eminence of the organizational reputation in the host market. However, this paper aims to examine the implications of marketing mix strategies on the product development issues in MNCs and/or retail industries. Through extensive literature mining from previous studies, this paper focuses on analyzing the effect of the strategic approaches used by most marketing experts to mediate the issues of product development. It intends to explore and cast light on the judicious role of the marketing mix in obtaining a competitive edge in most MNCs/retail firms. In the process, it also covers the relationship between the four basic components of the marketing mix, the 4Ps. The paper highlights how the marketing mix can influence the intricacies pertaining to the development process of a product. The study has the potential to provide managers with manual assistance on how these marketing strategies should be implemented and expanded to ameliorate business performance.
\end{abstract}

Keywords: Marketing strategies, Multinational companies, revenues, retail industries, global marketing, international marketing.

\section{Introduction}

Global marketing has increasingly become a trend for various multinational companies (MNCs) across the world to serve new customers and generate broad revenues for the business. Particularly for the product development of a company, a strong marketing mix strategy is highly solicited for business experts. Marketing mix strategies correspond to the actions undertaken by an organization to market its products or service (Abril \& Rodriguez-Cánovas, 2016). The marketing mix explicitly helps an organization segregate its marketing initiatives based on the task in a process-driven manner that influences the overall product or service development procedure in a domestic or global market. Typically, a marketing mix strategy works as a comprehensive and simplified framework to break the four most vital components of marketing. This framework has been evolving for decades. While some of the elements have been added or modified with time, but the core components of the marketing mix have categorically remained consistent for decades (Khan, 2014). When synchronized, the elements succinctly provide a well-built approach to effective marketing strategy. This includes the 4 Ps as follows:

- Product.

- Price.

- Place. 


\section{- Promotion.}

Given the present scenario of the globalized market, various organizations experience internalization of their business activities and operations to remain competitive. Also, with the successive reduction in regional barriers, it has been possible to bestow attractive opportunities for many businesses outside their conventional home markets (Baker, 2012). Besides, the new technological refinements have also presented adequate possibilities for various MNCs and retail firms to exploit the resources of the industrial structure and establish their foothold in foreign markets.

\section{Marketing mix strategies in MNCs and Retail}

For MNCs, it has been typically observed that as most global business functionalities get involved in the overseas markets, the management team needs to take a range of vital marketing decisions and develop strategic approaches that are made within a less familiar environment. This lack of familiarity often results in improper marketing strategies that do not suit the foreign markets (Pour, Nazari \& Emami, 2013). However, the responsibility of these MNCs lies in adopting the appropriate marketing strategies by following the 4Ps in order to accomplish their business objectives as a priority. At the same time, the global advocacy of financial liberalization has paved the way for various MNCs to formulate these marketing mix strategies based on the customer preferences of the foreign market. Not only MNCs, but the retail marketing mix has also developed over the years and is prevalent in many countries. It is worth exploring to see how these 4Ps shape and inform succinct decision-making of the management team in retailing. Often retail managers use the marketing mix strategies as a comprehensive guide but they need to be strictly aware of the necessity to consider every aspect of their business situation while planning marketing strategies and implementations (Al-Qarni et al., 2013). However, retail managers use a variety of combinations of these elements to obtain promotional and organizational objectives. The extent and form of the elements and their utility always depends upon the objectivity and target goal of the retail company, products, resource availability, and above all market profile. Small retailers typically depend on materials (point-of-purchase) as provided by the firms that provide merchandise.

For the retail businesses, the marketing mix concept is to place the right product at the most appropriate time, at the right place, and at the right price to entice potential consumers. However, the challenge lies in conducting these tasks well. While for a big MNC, the strategic approaches are stronger and more effective, for a small-scale retail firm intending to expand its foothold outside the home market, requires an effective and well-defined marketing mix strategies to avoid hefty losses. In order to ensure maximum sales, most retail managers create a defined plan with executable steps and metrics by which they can measure success and grab information about the acceptance of the product in the target market (Sarker, Aimin \& Begum, 2012). For each product, a retailer must have a thorough comprehension of the product value, its uniqueness, the pricing details, and where he wants to sell it. Additionally, many retailers captivate the attention of customers through promotional events (Blut, Teller \& Floh, 2018). If these strategies are in place, product development and expansion is most likely to be fruitful.

This study, therefore, seeks to explore and assess the impact of marketing mix strategies on the range of issues concerning product development in multinational companies and retail industries. In this process, the study also aims to determine the probable benefits these companies obtain from their selection of marketing strategies. This is done in view of appreciating the marketing involvement of MNCs and retail firms and propose relevant recommendations to help them perform better in the future.

\section{Concepts of marketing mix strategies and multinational companies}

MNCs and marketing mix strategies as concepts have varied views as put forward by different management scholars. For an MNC, the marketing mix is the most simplified tool with interdependent variables that help the business to determine a clear and grounded strategy to develop and bring a product to its domestic or target market. Most MNCs use standardized marketing mix approaches to build and implement a potent marketing strategy. These strategies are used by the management team of MNCs to show valued prospects concerning why a particular product is better than the potential competitors. 


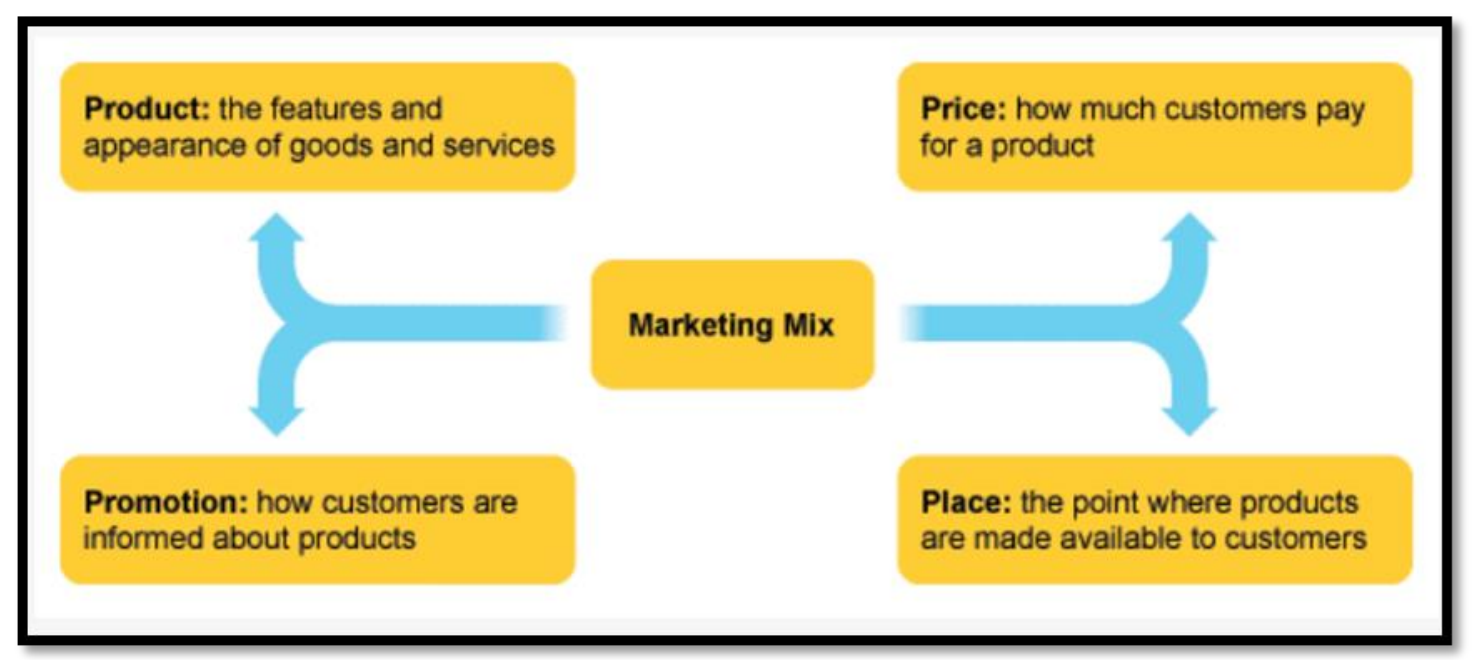

Figure 1: Schematic of marketing mix strategies (4Ps)

(Source: Bbc.co.uk 2020)

The marketing mix is often viewed as a defined marketing logic by means of which an organization hopes to accomplish its target objectives (Nath, Nachiappan \& Ramanathan, 2010). This is why it comprises specified blueprints for target markets, levels of marketing expenditure, and above all effectively positioning its distinct marketing mix. Ideally, a company's marketing mix strategies have a humongous impact on its product development that in turn impacts the company's overall revenue attainment. It is therefore considered to be a big picture of what an organization does in certain markets to grab success. MNCs are often considered to have defined subsidiaries and sales opportunities all across the globe. Besides, MNCs have appropriate infrastructure for marketing and production in different nations depending on overseas income (Khan, 2014). The more countries in which these MNCs operate, the more it would seek to avoid government regulations on restrictions. It could also be described as companies where product development criteria are based on how well the marketing mix approaches are integrated and embraced by the target audience.

\section{Product strategy}

For an MNC or retail firm, it is pointless to develop a product that customers are reluctant to purchase. Yet many companies decide the strategy of offering a product first and thereafter hope to secure a market for it. According to marketing experts, product development is said to be perfect if it provides value for the consumers. This essentially means that the business must provide its consumers what it wants and not what it perceives its customers want. Products are the most crucial elements that categorically determine the brand image of the business (Huang \& Sarigöllü, 2014). By implementing rigid and potent product strategies, a business can entice a large number of consumers. On the other hand, if the product development strategy is unstable, the business will fail to heighten its sales and organizational performance. Hence, it is important the businesses standardize the product quality before marketing it and integrate sustainable marketing mix strategies to market the same in multiple countries as per consumer requirements and custom laws. Also, a business should adapt to the difference in consumer needs to avoid product development intricacies. This also means that a business needs to strategically customize its products aligned with the needs of the target customers.

\section{Pricing strategy}

Price is the second element of the marketing mix. For a marketer, the pricing strategies of a product immensely impact its development and expansion. Pricing is referred to as the value charged for any particular product. For a business expert, fixing the price is one of the most challenging processes as a lot of factors come into consideration (Gunawan \& Wahyuni, 2018). This includes the product necessity, cost involved, customer liability, rules and norms, government restrictions, pricing, and budget charged by other competitors for similar products, and others. Each of these factors stringently impacts product development and its popularity among consumers even in entrepreneurial firms. Hence, formulating the pricing strategies 
is one of the most crucial parameters of a business as it influences the profitability of the business. As per Porter's generic approaches, a business has different pricing strategies.

Cost leadership is an approach used by a business to enhance its efficiencies and decrease production costs well below the industry average. If a business chooses this strategy, it can set the budget of its products below its closest competitors and draw the attention of more customers. This strategy helps to eliminate competitors and control issues of product development in the competitive global market.

Differentiation: Many businesses also choose to implement a differentiation strategy that succinctly distinguishes a product from other products of a similar category offered by potential market competitors (Abril \& Rodriguez-Cánovas, 2016). By adopting this strategy, a business focuses to offer a range of unique product development with respect to design, quality, consumer service, features, and others rather than focusing just on cost. Thus, a company would set a relatively higher price margin than its competitors for its product development but offers unique features that facilitate added values in the product types.

\section{Place strategy}

The third element is the product strategy that refers to locations, channels of distribution, and means of delivering a range of products to its customers. A thorough understanding of the positioning or place of the product development is highly solicited for MNCs or retail firms as it influences the long-term success and prominence of product development. Besides, a product's geographic location also has a huge impact on business profitability (Singh, 2012). Hence, it is always recommended to opt for a suitable place that is easily accessible to potential customers. If not, the product would lose adequate consumer attention and eventually lose its adaptability in the target market. Retailers must be located near the target audience or wherever the availability of labor and raw materials is easier that ensures product accessibility. Retail stores situated far away from potential buyers would have a huge negative impact on their purchase intention as it decreases their frequency of visiting the physical stores.

\section{Promotion strategy}

The promotional strategy of product development is one of the most impactful tools used by MNCs or retail businesses to ameliorate their sales performance (Abril \& Rodriguez-Cánovas, 2016). Promotional strategies significantly help to boost customer awareness on product development resulting in heightened sales that promote brand loyalty. Promotional strategies include a wide variety of methods including sales promotions, direct marketing, discounting, giveaways, advertising, and above all public relations. Also communication helps in less misunderstanding and improves the procedures and processes and creates great efficiency. (Kalogiannidis, 2020). According to (Kalogiannidis \& Melfou, 2020) through social media, direct contact between MNCs and customer is developed which helped in removing agents and middlemen.

\section{The competitive advantage}

The framework of strategic competitive advantage has been developed by Porter. This framework eventually became a model for strategic thinking by which most MNCs and retail firms think about how to emerge offering better than potential competitors in the dynamic market. Competitive advantage refers to the value that a business creates for its consumers in a way by which it outperforms its potential rivals. This is done by providing uniform benefits or more unique and advanced products than competitors. Competitive advantage is directly related to the marketing mix strategies by which an organization achieves a more favorable position than its prospective customers. While good quality and enhanced performance ensure competitive advantage for a business, it is also important to ascertain a range of factor conditions that determine the fate of its product development (Smith \& Merritt, 2020). An MNC or retail business strives to sustain itself in the convoluted market by differentiating its product line in terms of pricing and quality.

\section{Marketing strategies impacting product development issues}

From the above discussion, it is apparently clear that all MNCs and retail businesses must implement effective marketing strategies based on the target market and audience to ensure they do not encounter significant issues of product development. Also, a robust marketing mix strategy enables a business to obtain a stern competitive edge (Leonidou, Katsikeas \& Morgan, 2013). This facilitates a business to 
categorically differentiate the quality of its product variety and create a superior value for its potential buyers thereby serving them better. In this regard, it is very important to identify areas that require distribution channels. These are crucial for a business in enhancing the level of its product availability and highlight the primary features through its marketing mix approaches.

A company that unable to specify the needs of the customers and create well-defined marketing strategies will not be able to successfully generate consumer attention and thereby lose its potential in the target market. It is the same across all organizations that result in a significant reduction in market share with respect to product development and its associated challenges. At the same time, it leads to the reduction of the profitable customer relationship as well that fails to ensure consistent survival of the business through successful product development (Khan, 2014). Therein lays the importance of adopting impregnable marketing mixes for the value creation of a company's product and consumer satisfaction.

The challenges of MNCs/Retail and Marketing in terms of marketing mix strategy implementation will only increase if the business experts and employers fail to bestow appropriate marketing strategies for their product development and expansion in the target market.

\section{Brief description of methods}

The current study includes relevant data from a plethora of secondary literature. It includes a range of qualitative data (authentic information) from peer-reviewed journals, books, articles, online reports from credible academic databases including Google Scholar and PubMed. For the comprehensive interpretation of the gathered data, an exploratory research design has been selected for the study. This is because the study intends to explore how the elements of the marketing mix strategy influence issues of product development in a variety of MNCs and retail marketing (Brei et al., 2011). Therefore, an exploratory research design has suited the intended purpose to strengthen the existing understanding of the research problem. However, this study does not intend to bifurcate the research topic to generate conclusive interpretations. It aims to offer a deeper comprehension of the study topic and links the major findings with the exhaustive literature review.

\section{Discussion and findings}

Most of the data obtained from the secondary sources imply the relevance of establishing powerful marketing strategies to facilitate market sustainability. At the same time, it is equally important that MNCs and retail firms integrate strategic product development based on customer choices to ensure its easier adaptability in the dynamic market (Kim \& Hyun, 2011). Most of the data suggest that these businesses need to implement projects that categorically affect product development in the best possible way so that they generate maximum revenues from it. This, in turn, would also impact the social and economic progress of the domestic and target markets. However, most MNCs and retail businesses can accomplish their mutual interest of an organization's corporate objective and the economic development of the country much better if these businesses implement defined projects that would make the eminence of their product development easier. If the sales department promises a certain product to deploy within a certain time frame and does not inform about such a promise to the engineering department then the result becomes the delay of the product manufacturing and the customers start losing the trust (Kalogiannidis 2020).

\section{Recommendations and conclusions}

In the end, it can be stated that most MNCs and retail firms need to employ an impregnable marketing mix of standardization in their marketing involvement in and outside their home markets. From the above discussion, it is clear that the defined elements of the marketing mix have a direct correlation with organizational performance (Aremu \& Bamiduro, 2012). This indicates that a stern strategy would remarkably affect the product development issues of a business in a positive or negative way. Based on the study findings, it is imperative that the potential strategy of the 4Ps would help to refine organizational performance and aid to boost the profitability of its product development. This would also contribute to the economic growth and flourishment of the businesses. Most successful MNCs including Apple and the retail industry develop a robust and stern mix strategy for their product categories. This is the reason behind their sustainability in the competitive market. Hence, it is of utmost importance the local or smaller companies 
also have a stern understanding of their marketing mix elements to ensure that their growing business sustains a prolonged period by expanding its domain in various other countries and influencing the strategic progress of its product development. Also according to (Kalogiannidis, Chatzitheodoridis \& Kontsas 2020) all MNC's need to be prepared on facing and reduce several kind of crisis.

Based on this, the following are a few recommendations to help MNCs and retailers obtain a competitive advantage.

I. The marketing environment of most $\mathrm{MNC}$ and retail businesses is immensely priced sensitive. Hence, all these industries must provide an affordable product range considering the income and earning potential of the buyers and their culture.

II. All MNCs and retail markets must develop quality products and performance in a way that addresses the issue of their product development. This aggravates the implementation of sustainable marketing mix strategies that provide them with a competitive edge over other competitors.

III. All MNCs and retail businesses must prioritize promotional activities in order to make their product development clear and enticing.

IV. Product development plays a major role in the case of existence as well as competitiveness for any MNCs or retail business (Kalogiannidis, Mavratzas 2020)

\section{References}

[1] Kalogiannidis, S. (2020). Impact of Effective Business Communication on Employee Performance. European Journal of Business and Management Research, 5(6).

[2] Baker, M. (2012). The marketing book. Routledge.

[3] Abril, C., \& Rodriguez-Cánovas, B. (2016). Marketing mix effects on private labels brand equity. European Journal of Management and Business Economics, 25(3), 168-175.

[4] Gunawan, A., \& Wahyuni, S. F. (2018). The Effect of Marketing Mix, Service Quality, Islamic Values and Institutional Image on Students' Satisfaction and Loyalty. Expert Journal of Marketing, 6(2)., 1-14.

[5] Kalogiannidis, S. (2020). Covid Impact on Small Business. International Journal of Social Science and Economics Invention, 6(12), 387 to 391. https://doi.org/10.23958/ijssei/vol06-i12/257

[6] Al-Qarni, A. A., Alsharqi, O. Z., Qalai, D. A., \& Kadi, N. (2013). The impact of marketing mix strategy on hospitals performance measured by patient satisfaction: an empirical investigation on Jeddah private sector hospital senior managers perspective. International Journal of Marketing Studies, 5(6), 210-227.

[7] Aremu, M. A., \& Bamiduro, J. A. (2012). Marketing mix practice as a determinant of entrepreneurial business performance. International Journal of Business and Management, 7(1), 205-211.

[8] Kalogiannidis, S., Melfou K. (2020). Issues and Opportunities for Agriculture Sector During Global Pandemic. International Journal of Economics, Business and Management Research, Vol. 4, No. 12; 2020, 204-211 ISSN: 2456-7760.

[9] Blut, M., Teller, C., \& Floh, A. (2018). Testing retail marketing-mix effects on patronage: A metaanalysis. Journal of Retailing, 94(2), 113-135

[10] Khan, M. T. (2014). The concept of'marketing mix'and its elements (a conceptual review paper). International journal of information, business and management, 6(2), 95-99.

[11] Brei, V. A., d'Avila, L., Camargo, L. F., \& Engels, J. (2011). The influence of adaptation and standardization of the marketing mix on performance: A meta-analysis. BAR-Brazilian Administration Review, 8(3), 266-287.

[12] Kalogiannidis, S., Mavratzas, S (2020). Impact of marketing mix strategies effective product development issues in MNCs/Retail. International Journal of Business Marketing and Management (IJBMM) Volume 5 Issue 12 December 2020, P.P. 118-125. ISSN: 2456-4559.

[13] Huang, R., \& Sarigöllü, E. (2014). How brand awareness relates to market outcome, brand equity, and the marketing mix. In Fashion Branding and Consumer Behaviors (pp. 113-132). Springer, New York, NY. 
[14] Kim, J. H., \& Hyun, Y. J. (2011). A model to investigate the influence of marketing-mix efforts and corporate image on brand equity in the IT software sector. Industrial marketing management, 40(3), 424-438.

[15] Kalogiannidis, S., Melfou K. (2020). Issues and Opportunities for Agriculture Sector During

[16] Global Pandemic. International Journal of Economics, Business and Management Research, Vol. 4, No. 12; 2020, 204-211 ISSN: 2456-7760.

[17] Kalogiannidis, S. (2020). Impact of Plant Closures on Urban and Regional Communities: A

[18] Case Study of South Australian Gas Industry and its Workers. International Journal of Economics and Business Administration, 8(4), 994-1010.DOI: 10.35808/ijeba/645

[19] Leonidou, C. N., Katsikeas, C. S., \& Morgan, N. A. (2013). "Greening” the marketing mix: Do firms do it and does it pay off?. Journal of the Academy of Marketing Science, 41(2), 151-170.

[20] Nath, P., Nachiappan, S., \& Ramanathan, R. (2010). The impact of marketing capability, operations capability and diversification strategy on performance: A resource-based view. Industrial Marketing Management, 39(2), 317-329.

[21] Kalogiannidis, S. (2020). Impact of Effective Business Communication on Employee Performance. European Journal of Business and Management Research, 5(6).

[22] Kalogiannidis, S., Chatzitheodoridis, F., Kontsas, S. (2020). An Eclectic Discussion of the

[23] Effects of COVID-19 Pandemic on the World Economy During the First Stage of the Spread. International Journal of Financial Research Vol. 11, No. 6, Special Issue; 2020 . 137-153. DOI:10.5430/ijfr.v11n6p137

[24] Pour, B. S., Nazari, K., \& Emami, M. (2013). The effect of marketing mix in attracting customers: Case study of Saderat Bank in Kermanshah Province. African Journal of Business Management, 7(34), 3272-3280.

[25] Kalogiannidis, S. (2020). Economic Cooperative Models: Agricultural Cooperatives in Greece and the Need to Modernize their Operation for the Sustainable Development of Local

[26] Societies. International Journal of Academic Research in Business and Social Sciences. 10(11), 452468. DOI:10.6007/IJARBSS/v10-i11/8035

[27] Sarker, M. A. H., Aimin, W., \& Begum, S. (2012). Investigating the impact of marketing mix elements on tourists 'satisfaction: An empirical study on east lake. European journal of business and management, 4(7), 273-282.

[28] Singh, M. (2012). Marketing mix of 4P's for competitive advantage. IOSR Journal of Business and Management, 3(6), 40-45.

[29] Smith, P. G., \& Merritt, G. M. (2020). Proactive risk management: Controlling uncertainty in product development. CRC Press.

[30] Kalogiannidis, S. (2017). The Role of Media in Disaster and Emergency Communication

[31] Models. Годишник на департамент" Масови комуникации", (1), 195-202.

[32] Kalogiannidis, S. (2015). The Role of media during a crisis Radio: The parameter of Analog broadcasting VS Digital broadcasting. Годишник на департамент" Масови комуникации", 20(1), 303-324.

[33] Kontogeorgos, A., Sergaki, P., \& Chatzitheodoridis, F. (2017). AN ASSESSMENT OF NEW FARMERS'PERCEPTIONS ABOUT AGRICULTURAL COOPERATIVES. Journal of Developmental Entrepreneurship, 22(01), 1750003.

[34] Chatzitheodoridis, F., Michailidis, A., Theodosiou, G., \& Loizou, E. (2013). Local cooperation: A dynamic force for endogenous rural development. In Balkan and Eastern European Countries in the Midst of the Global Economic Crisis (pp. 121-132). Physica, Heidelberg. 